\title{
Specific Production of Free-Living Marine Nematodes
}

\author{
V. E. Zaika and N. P. Makarova \\ Institute of Biology of South Seas, Ukranian Academy of Sciences, Sevastopol, USSR
}

ABSTRACT: Using the data available on generation time, life span, and number of eggs for marine nematodes, the daily specific production has been calculated. For approximate estimations of the specific production (C) for nematodes in natural populations as a function of water temperature $\left(\mathrm{T}^{\circ}\right)$ the following equation is proposed: $C=0.08 T^{0.96}$.

\section{INTRODUCTION}

Production in animal populations has received detailed attention in 'Marine Ecology', Volume IV (Greze, 1978). For solving a number of ecological problems we concentrate here on the productivity of communities which inhabit different biotopes. Since it is impossible to study the production of all species of a community, it is important to formulate regular quantitative relations between 'common' biological variables and population production. For this purpose, it is extremely important to ascertain the laws governing the value of daily specific production $C=P / B$, where $P=$ daily production, $B=$ average biomass for some 'typical' species and groups under different environmental conditions (Zaika, 1972, 1974).

In this report the results of analysis of specific production values are presented for free-living marine nematodes - one of the main groups of meiobenthos animals.

\section{METHOD OF ESTIMATION AND INITIAL DATA}

The specific production of nematodes may be estimated on the basis of biological literature data (for review consult Kinne, 1977, pp. 691-709). There are different possibilities of calculation. Proceeding from the character of the data available the method of analysing potential population growth is considered to be the best one.

For this method we use data on generation time $\left(\tau_{\mathrm{o}}=\right.$ time between identical stages in two successive generations), average duration of life $\left(\tau_{\mathrm{m}}\right)$ and general number of eggs deposited by the female $\left(N_{o v}\right)$.

The data presented for $\tau_{0}, \tau_{\mathrm{m}}$ and $N_{\mathrm{ov}}$ by different authors are summarized in Table 1 . Whether this 'sample' is representative for mass species of marine nematodes from different regions of the World Ocean remains unknown. We suggest that size variety among mass meiobenthic nematodes and, hence, the variablity of $\tau_{\mathrm{o}}, \tau_{\mathrm{m}}, N_{\mathrm{ov}}$ is not larger than that of the species studied.

Figure 1 presents the size distribution of Black Sea nematodes (data from Vodyanitsky, 1968). Note that $85 \%$ of the species have sizes between 0.5 and $5 \mathrm{~mm}$. About the same limits pertain to mass species of nematodes in the Weser Estuary (Skoolmun and Gerlach, 1971).

\section{SCHEME OF C CALCULATION}

The general basis of the method employed, as well as a number of assumptions have been accounted for by Zaika (1972). One point must be stressed here: some investigators consider production calculations incorrect unless rates of elimination are included. Gerlach (1972) considered possible $C$ values of marine nematodes, based on hypothetic daily mortality rates as a function of age. However, it is not necessary to take into account elimination rates in our method of $C$ calculation.

The method is based on the following fact: providing the rate of new biomass formation is proportionate to population number, the specific production equals the 
Table 1. Development and reproduction of marine nematodes under experimental conditions

\begin{tabular}{|c|c|c|c|c|c|}
\hline Species & $\begin{array}{c}\text { Temperature } \\
\left({ }^{\circ} \mathrm{C}\right)\end{array}$ & $\begin{array}{c}\text { Egg } \\
\text { number } \\
\text { (average) }\end{array}$ & $\begin{array}{l}\text { Average } \\
\text { Generation } \\
\text { time (days) }\end{array}$ & $\begin{array}{c}\text { Average } \\
\text { lifespan } \\
\text { (days) }\end{array}$ & Source \\
\hline Adoncholaimus thalassophygas & $20-22$ & 17 & 63 & 78 & Gerlach and Schrage, 1971 \\
\hline Acanthonchus cobbi & - & - & 29 & - & ." \\
\hline Chromadorita tenuis & $20-22$ & 20 & 26 & 43 & , \\
\hline Chromadora macrolaimoides & 25 & - & 22 & 45 & Tietjen and Lee, 1973 \\
\hline Desmodora scaldensis & 7 & $>6$ & $\sim 730$ & 603 & Gerlach and Schrage, 1971 \\
\hline D. ocellata & $20-22$ & 22 & 29 & 56 & ." \\
\hline D. ocellata & 30 & - & 6 & - & Hopper et al., 1973 \\
\hline D. ocellata & 24 & - & 11.5 & - & ." \\
\hline D. ocellata & 21 & - & 12 & - & " \\
\hline D. ocellata & 18 & - & 43 & - & ," \\
\hline Diplolaimelloides oschei & $20-22$ & 36 & 29 & 54 & Gerlach and Schrage, 1971 \\
\hline D. islandica & $20-22$ & 22 & 31 & 50 & " \\
\hline D. sp. & 30 & - & 4.5 & - & Hopper et al., 1973 \\
\hline D. sp. & 24 & - & 7 & - & " \\
\hline D. sp. & 21 & - & 9.5 & - & ," \\
\hline D. sp. & 18 & - & 14 & - & ," \\
\hline D. sp. & 12 & - & 30 & - & ." \\
\hline Enoplus paralittoralis & 28 & - & 21 & - & " \\
\hline E. paralittoralis & 24 & - & 22 & - & " \\
\hline E paralittoralis & 21 & - & 41 & - & " \\
\hline Euchromadora gaulica & - & - & 35 & - & Gerlach and Schrage, 1971 \\
\hline Halichoanolaimus robustus & 7 & - & $>730$ & 855 & Gerlach and Schrage, 1972 \\
\hline Haliplectus dorsalis & 30 & - & 27 & - & Hopper et al., 1973 \\
\hline H. dorsalis & 24 & - & 34 & - & .' \\
\hline H. dorsalis & 21 & - & 70 & - & " \\
\hline Monhystera disjuncta & $20-22$ & 16 & 23 & 33 & Gerlach and Schrage, 1971 \\
\hline M. disjuncta & $17-22$ & 37 & 13 & 61 & 1, \\
\hline M. disjuncta & $13-15$ & - & 15 & - & " \\
\hline M. disjuncta & $9-12$ & - & 17 & - & " \\
\hline M. disjuncta & 7 & - & 22 & - & " \\
\hline M. disjuncta & $0-2$ & - & 77 & - & " \\
\hline M. disjuncta & $1-1$ & - & 135 & - & ". \\
\hline M. filicaudata & $20-25$ & $8-20$ & $24-35$ & - & ". \\
\hline M. parelegantula & - & - & 30 & - & "' \\
\hline M. denticulata (at $26 \%$ ) & 25 & $18-23$ & 10 & 34 & Tietjen and Lee, 1972 \\
\hline M. denticulata ". & 15 & $18-24$ & 18 & 53 & ," \\
\hline M. denticulata " & 5 & $10-17$ & 180 & 330 & ". \\
\hline Oncholaimus brachycercus & 7 & $>6$ & 180 & 610 & Gerlach and Schrage, 1972 \\
\hline O. oxyuris & 5 & 13.5 & - & - & Heip et al., 1978 \\
\hline O. oxyuris & 10 & 18.5 & - & - & "1 \\
\hline O. oxyuris & 15 & 34.3 & 152 & - & ," \\
\hline O. oxyuris & 20 & 35.6 & 114 & - & " \\
\hline O. oxyuris & 25 & 36.8 & 102 & - & " \\
\hline Oncholaimus sp. & 30 & - & 20 & - & Hopper et al., 1973 \\
\hline O. sp. & 24 & - & 2.25 & - & ," \\
\hline O. sp. & 21 & - & 39 & - & ". \\
\hline$O . \mathrm{sp}$ & 18 & - & 86 & - & ." \\
\hline Rhabditis marina & 33 & - & 1.5 & - & " \\
\hline R. marina & 24 & - & 2.25 & - & " \\
\hline R. marina & 21 & - & 2.5 & - & . \\
\hline R. marina & 18 & - & 4 & - & .. \\
\hline R. marina & 12 & - & 8 & - & ". \\
\hline Theristus pertenuis & $17-22$ & - & 23 & - & Gerlach and Schrage, 1971 \\
\hline T. pertenuis & $13-15$ & - & 41 & - & ." \\
\hline T. pertenuis & $9-12$ & - & 47 & - & $\because$ \\
\hline T. pertenuis & 7 & - & 71 & - & ." \\
\hline
\end{tabular}


reproduction coefficient reflecting the numerical increase in the absence of elimination. Hence, the $C$ value must be estimated as the specific rate of potential growth, not as 'intrinsic rate of increase', actually observed in the presence of elimination.

The specific production is calculated as

$$
C=\frac{\log N_{2}-\log N_{1}}{t_{2}-t_{1}}
$$

where $N_{1}$ and $N_{2}=$ numbers of individuals at times $t_{1}$ and $t_{2} ; N_{2}$ is estimated either by geometrical progression of potential population growth or experimentally, providing it is possible to neglect elimination.

However, if calculation according to equation (1) is based on a real $N_{2}$ in the presence of elimination, we obtain an underestimation of the $C$ value. This is why $C$ must be calculated without elimination.

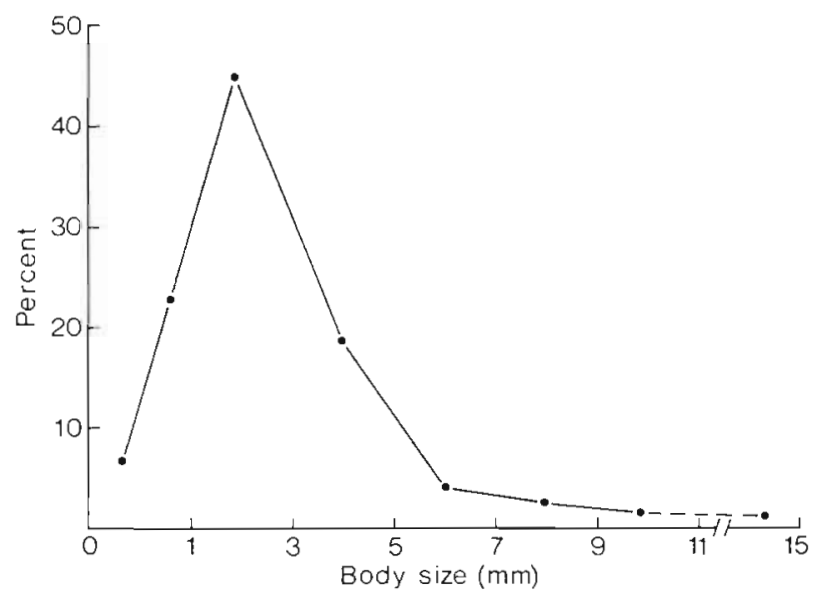

Fig. 1. Size distribution of Black Sea nematodes

In general, the specific production is completely defined by the reproductive potential, individual growth rate, and age structure of a population. The production value (but not $C$ !) depends on the biomass present. Elimination influences the number and biomass levels and therefore production. It influences the specific production only if changes in age-structure are caused.

Now we come to the limitations of the method of $C$ calculation. The method under discussion is precise enough when the age structure is constant, i. e. with mortality distributions according to age. It permits to ignore the population structure and to consider all individuals to be conventially identical. Hence it is necessary to use the method of $C$ calculation over rather long periods of time, i.e. at $\left(t_{2}-t_{1}\right) \geqslant \tau_{0}$.

Indeed, in the case of large long-lived animals with seasonal reproduction the calculation of $C$ with Equation (1) over short periods is meaningless: in one season adults with growth rates close to 0 may predominate while in another one population may consist mainly of quick growing juveniles. But if we consider periods not shorter than $\tau_{0}$, the method discussed will yield satisfactory specific-production estimation average values for the whole period.

The precision of the method increases with decreasing of animal sizes $\tau_{\mathrm{m}}$ and $\tau_{\mathrm{o}}$. Thus far, this method has only been used for bacteria and unicellular organisms. However, it is suitable also for metazoans as nematodes.

In order to obtain a geometrical progression of potential growth values for a population, Gerlach (1972) used the following initial data: $\tau_{0}=26$ days, $\tau_{\mathrm{m}}=34$ days, $N_{\mathrm{ov}}=20 ;$ male : female ratio $=1$. Hence a pair of nematodes will yield 22 offspring in 26 days; 220 , in 52 days; 2200 , in 78 days.

Using Equation (1) for such population growth rate we obtain $C=0.09$. For a precise estimation of the average $C$ value over the whole year it is necessary to know the characteristics of seasonal $\tau_{\mathrm{o}}$ changes, taking $N_{\text {ov }}$ as invariable.

Gerlach (1972) assumed that nematodes produce 12 generations per year; assuming further a certain mortality rate as a function of age and making use of growth curves for calculation, he obtained a yearly turnover rate of 26, corresponding to an average annual $C$ of 0.07 . Taking into account the fact that the water temperature near Helgoland exceeds $15^{\circ} \mathrm{C}$ only during 2.5 months each year and the data of Table 1 concerning the influence of temperature on $\tau_{0}$, the results obtained by Gerlach may be considered realistic, even though his $C$ estimates are too complex.

According to Table 1, $N_{o v}=20$ can be taken as average value for all nematodes. The fact that $\tau_{\mathrm{m}}>\tau_{\mathrm{o}}$ is not significant for $C$ calculations, since the presence or absence of individuals of previous generations does not affect the calculation. Hence, for further calculations Equation (1) may be simplified taking $t_{2}-t_{1}=\tau_{\mathrm{o}}$ and assuming for meiobenthic nematodes the following law of potential numerical growth: $2-20-200-2000 \ldots$, with the step $\tau_{0}$ so that

$$
C=\frac{2.3}{\tau_{\mathrm{o}}}
$$

\section{SPECIFIC PRODUCTION OF NEMATODES AS A FUNCTION OF TEMPERATURE}

We must distinguish at least between 2 master factors which influence $\tau_{0}$ and $N_{\text {ov }}$ of all poikilothermal animals: temperature and nutrition. Both may become limiting factors in any part of the distributional area of a species. Other factors such as salinity undergo appreciable fluctuations only in some marine biotopes, while such factors as population density or predation 
rate cannot influence the characteristics discussed in marine nematodes.

Table 1 shows that the influence of temperature was studied for a number of species. Specific-production values obtained from such data might be a little higher than in the sea, since natural food conditions are usually not as favourable as in experiments. We have calculated specific-production values, using Equation (1), excluding data obtained at extremely high temperatures (Hopper et al., 1973).

Our results are listed in Table 2. The variability of the $C$ values is, at some temperature intervals, high; this is not surprising, since the investigations were conducted both with nematodes of the North Sea and a mangrove belt. The extremely high $C$ values for $R$ habditis marina are of great interest; they are just as high as those of rotifers and infusorians (Zaika, 1972). $R$. marina clearly falls out of the general range and hence was excluded from calculations. In addition it seems that while developing so quickly $R$. marina might not attain $N_{o v}=20$. The average $C$ values from Table 2 may be used for estimating nematode production in natural communities. $R$. marina is of non-marine origin, but we do not consider this fact as a reason for the peculiarities mentioned. The dependence of average $C$ values on temperature is presented graphically in Figure 2. In order to determine the equation for describing these empirical dependences, it was previously established that the points characterizing the thermal dependence of $\tau_{0}$ of different species, lie on straight lines in logarythmic coordinates. This means that the dependencies can be represented as

$$
\tau_{0}=a T^{b}
$$

where $T=$ temperature; $a$ and $b=$ constants.

For describing the dependence between development times of poikilothermal animals and temperature, usually the Beleradek equation is used (Corkett

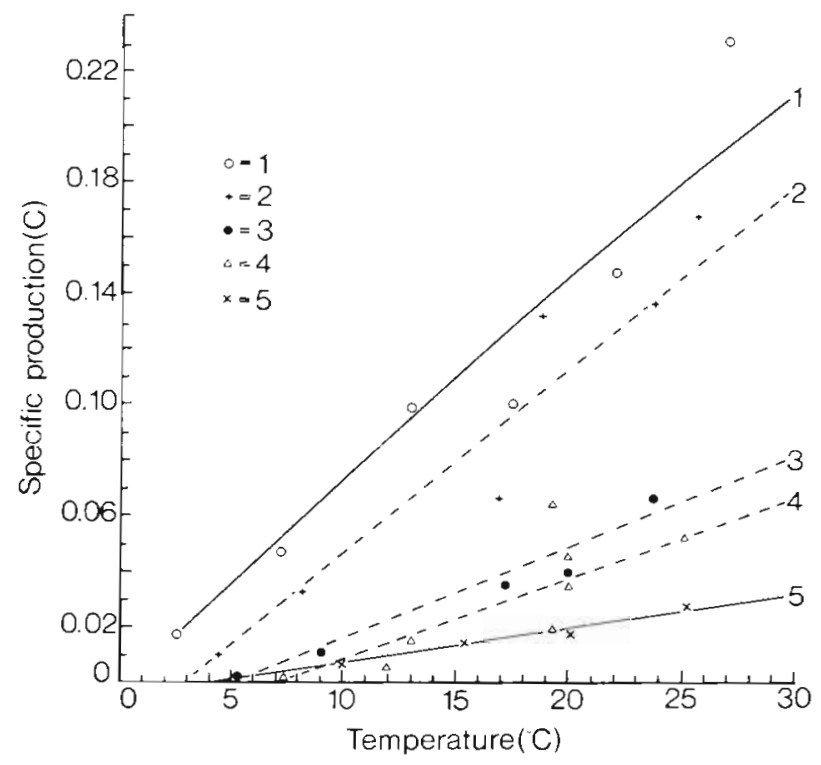

Fig. 2. Dependence of average $C$ values $\left(\right.$ day $\left.^{-1}\right)$ on temperature. 1: average for marine nematodes; 2: Acartia clausi; 3: Calanipeda aquae-dulcis; 4: Orchestia bottae (2-4 crustaceans, from Zaika, 1972); 5: Oncholaimus oxyuris (from Heip et al., 1978). Curve 1 based on the Equation (5); Curves 2-5 eyefitted

and McLaren, 1970). The only difference between Equation (2) and the Beleradek equation is that the curve passes through the original coordinate.

Substituting $\tau_{0}$ in Equation (2) in accordance with (3) we get

$$
C=\frac{2.3}{a} \cdot T^{-b}
$$

From the average data of Table 2, using the least square method, we find the numerical values of $a$ and $b$ in Equation (4):

$$
C=0.08 T^{0.96}
$$

\begin{tabular}{|c|c|c|c|c|c|c|}
\hline \multirow[b]{2}{*}{ Species } & \multicolumn{6}{|c|}{ Temperature $\left({ }^{\circ} \mathrm{C}\right)$} \\
\hline & $0-5$ & $5-10$ & $10-15$ & $15-20$ & $20-25$ & $25-30$ \\
\hline Diplolaimella ocellata & - & - & - & 0.05 & 0.20 & 0.38 \\
\hline Diplolaimelloides sp. & - & - & 0.08 & 0.16 & 0.28 & 0.50 \\
\hline Enoplus paralittoralis & - & - & - & - & 0.08 & 0.11 \\
\hline Haliplectus dorsalis & - & - & - & 0.02 & 0.05 & 0.08 \\
\hline Monhystera disjuncta & 0.03 & 0.10 & 0.14 & 0.18 & - & - \\
\hline M. denticulata & 0.01 & 0.01 & 0.13 & 0.13 & 0.23 & 0.23 \\
\hline Rhabditis marina & - & - & 0.29 & 0.57 & 0.97 & 1.15 \\
\hline Theristus pertenuis & - & 0.03 & 0.06 & 0.10 & - & - \\
\hline Oncholaimus sp. & - & - & - & 0.03 & 0.07 & 0.11 \\
\hline Average $C$ (excluding $R$. marina) & 0.02 & 0.05 & 0.10 & 0.10 & 0.15 & 0.23 \\
\hline$C$ limits (excluding $R$. marina) & $0.01-0.03$ & $0.01-0.10$ & $0.06-0.14$ & $0.02-0.18$ & $0.05-0.28$ & $0.08-0.50$ \\
\hline
\end{tabular}

The corresponding curve is shown in Figure 2. Com-

Table. 2. Specific production of nematodes at different temperatures 
paring equations (5) and (4) we obtain $a=287$; and for (3) we have

$$
\tau_{\mathrm{o}}=287 T^{-0.96}
$$

Equation (5) and Figure 2 allow to estimate approximately the production of marine nematodes. It is necessary to know the nematodes biomass and the water temperature. Presumably the pattern of this dependence is not random as are the same kind of $C$ and temperature relations established earlier for some marine crustaceans (Zaika, 1972). The corresponding data are shown in Figure 2.

\section{OTHER APPROACHES TO SPECIFIC-PRODUCTION ESTIMATION}

There exists an empirical dependence between the daily specific production and life span; this statement is based on data obtained from the different animal species (rotifers to fishes; Zaika, 1972, Fig. 30). Comparing the data of Table 1 with the dependence, it may be seen that in the temperature interval $15^{\circ}-25^{\circ} \mathrm{C}$, the average value $\tau_{\mathrm{m}}$ of the nematode species studied is 33-78 days; that corresponds to a $C$ of $0.06-0.15$. At low temperatures, $\tau_{\mathrm{m}}$ can be about one year and the corresponding $C$ would be about 0.01

Finally, it is possible to use an individuals growth data for estimating its specific production.

The daily specific rate of linear growth, averaged for the period from hatching to maturation, has been calculated for two species of nematodes according to the growth curve (Tietjen and Lee, 1972, 1973) employing the equation

$$
q_{1}=\frac{\log l_{2}-\log l_{1}}{t_{2}-t_{1}}
$$

where $q_{1}=$ daily specific rate of linear growth; $l_{1}$ and $l_{2}$ $=$ body length at times $t_{1}$ and $t_{2}$. We obtain the following $q_{1}$ values

$\begin{array}{lcc} & 25^{\circ} \mathrm{C} & 15{ }^{\circ} \mathrm{C} \\ \text { Monhystera denticulata: } & 0.19 & 0.14 \\ \text { Chromadora macrolaimoides: } & 0.15 & -\end{array}$

The weight-length dependence is

$$
w=m l^{3}
$$

where $w=$ individual weight $m=$ constant.

For the specific rate of weight growth $\left(q_{w}\right)$ we have

$$
q_{w}=\frac{\log w_{2}-\log w_{1}}{t_{2}-t_{1}}
$$

Substituting $w$ in Equation (9) in accordance with (8) we obtain:

$$
q_{w}=3 q_{1}
$$

Equation (10) is adequate for calculating specific rates of weight growth from linear growth data. Wher- ever in Equation (8) the power at $w$ differs from 3 , it is sufficient to use in Equation (10) the corresponding value instead of 3

Employing Equation (10) for the species discussed at temperatures between $15^{\circ}$ and $25^{\circ} \mathrm{C}$ we get:

$$
q_{\mathrm{w}}=0.42-0.57
$$

Gerlach (1972) used the curve of weight growth for calculating turnover rate in Chromadora tenuis. Using his growth data for the period from the hatching to maturation, Equation (9) gives

$$
q_{\mathrm{w}}=0.38
$$

Thus for three species of marine nematodes we now have average daily specific rates of weight growth for the period of active development. For estimating the specific production it is necessary to know also the age structure of the population concerned - in this case the ratio juvenile to adult biomass. If $20 \%$ of the general biomass consists of actively growing individuals, the specific production of that population is $0.08-0.12$ (at $15^{\circ}-25^{\circ} \mathrm{C}$ ).

Finally, it was shown by Zaika (1972) that the intrinsic rate of increase $r$ provides a minimal estimation of the average specific production rate. Data on $r$ values for Oncholaimus oxyuris at different temperatures are available (Heip et al., 1978). It is interesting that the relationship between $r$ and temperature is nearly linear. Assuming $C \approx r$ we have for $O$. oxyuris the same kind of curve, as for other nematodes and crustaceans (Fig. 2). These data were not included in calculations of average $C$ values for nematodes, since $O$. oxyuris has large dimensions and a long generation time.

After completion of the present manuscript the authors, thanks to assistance from Prof. Kinne, got an opportunity to acquaint themselves with the paper by Tietjen and Lee (1977), containing data on $r$ and $\tau_{0}$ for Chromadorina germanica at different temperatures. Estimating $C$ according to the expression $C \approx r$ and Equation (2) for C. germanica, we obtain similar values. From comparing $C$ dependence on temperature for $C$. germanica with Curve 1 in Figure 2, it follows that, in the temperature range $17^{\circ}-23^{\circ} \mathrm{C}$, the $C$ values are practically identical - although, in general, the curve obtained for $C$. germanica has a different slope. The data by Tietjen and Lee (1977) suggest that the nematodes' reaction signals close-to-lethal temperatures. Such cases should probably be excluded from analysing general dependencies similar to those expressed by Equations (5) and (6).

The results of our analysis indicate high average specific production rates of marine nematodes, and allow to estimate very quickly nematods productions in different marine biotopes, using data on biomass, age structure and water temperature. The methods of $C$ 
calculation discussed allow to conduct a more profound analysis of the production process in this important group of meiobenthos animals (Gerlach, 1971; Juario, 1975), providing the corresponding data are at hand.

Acknowledgement. The authors wish to acknowledge the valuable help in obtaining some data and the editing of the English version of this manuscript by Prof. O. Kinne.

\section{LITERATURE CITED}

Corkett, C. J. and McLaren I. A. (1970). Relationships between development rate of eggs and older stages of copepods. J. mar. biol. Ass. U. K., 50, 161-168.

Gerlach, S. A. (1971). On the importance of marine meiofauna for benthos communities. Oecologia, 6, 176-190.

Gerlach, S. A. (1972). Die Produktionsleistung des Benthos in der Helgoländer Bucht. Verh. dt. zool. Ges., 65, 1-13.

Gerlach, S. A. and Schrage, M. (1971). Life cycles in marine meiobenthos. Experiments at various temperatures with Monhystera disjuncta and Theristus pertenuis (Nematoda). Mar. Biol, 9, 274-280.

Gerlach, S. A. and Schrage, M. (1972). Life cycles at low temperatures in some free-living marine Nematodes. Veroff. Inst. Meeresforsch. Bremerh, 14, 5-11.

Heip, C., Smol, N. and Absillis, V. (1978). Influence of temperature on the reproductive potential of Oncholaimus oxyuris (Nematoda: Oncholaimidae). Mar. Biol., 45, $255-260$.

Greze, V. N. (1978). Production in animal population. In O. Kinne (Ed.), Marine Ecology, Vol. IV, Dynamics. Wiley, Chichester. pp. 89-114.
Hopper, B. E., Fell, J.W and Cefalu, R. C. (1973). Effect of temperature on life cycles of nematodes associated with the mangrove (Rhizophora mangle) detritial system. Mar Biol, 23, 293-296.

Juario, J. V (1975). Nematode species composition and seasonal fluctuation of a sublittoral meiofauna community in the German Bight. Veröff. Inst. Meeresforsch. Bremerh. $15,283-337$

Kinne, O. (1977). Cultivation of animals : research cultivation. In O. Kinne (Ed.) Marine Ecology, Vol. III, Cultivation, Part 2. Wiley, Chichester. pp. 579-1293.

Skoolmun, P. and Gerlach, S. A. (1971). Jahreszeitliche Fluktuationen der Nematodenfauna im Gezeitenbereich des Weser-Ästuars (Deutsche Bucht). Veröff. Inst. Meeresforsch. Bremerh., 13, 119-138.

Tietjen, J. H. and Lee, J. J. (1973). Life cycles in marine nematodes. Influence of temperature and salinity on the development of Monhystera denticulata Timm. Oecologia, 10,167-176.

Tietjen, J. H. and Lee, J. J. (1973). Life history and feeding habits of the marine nematode, Chromadora macrolaimoides, Steiner. Oecologia, 12, 303-314.

Tietjen, J. H. and Lee, J. J. (1977). Life histories of marine nematodes. Influence of temperature and salinity on the reproductive potential of Chromadorina germanica Bütschli. Mikrofauna Meeresboden, 61, 263-270.

Vodyanitsky, V. A. (Ed.) (1968). INDEX of the Black and Azov Seas Fauna, (Russ.), Naukova Dumka, Kiev.

Zaika, V. E. (1972). Specific Production of Aquatic Invertebrates, (Russ.), Naukova Dumka, Kiev. (Engl. transl. 1973, Halsted Press, Jerusalem, London, Wiley, New York, Toronto).

Zaika, V. E. (1974). Community productivity and optimum exploitation of biological resources. In Proceedings of the Intemational Congress of Ecology. Pudoc, Wageningen. pp. $60-61$

This manuscript was presented by Professor M. E. Vinogradov; it was accepted for printing on July 3, 1979 